\title{
Humpback whale Megaptera novaeangliae song reveals wintering activity in the Northwestern Hawaiian Islands
}

\author{
Marc O. Lammers ${ }^{1,2, *}$, Pollyanna I. Fisher-Pool ${ }^{2}$, Whitlow W. L. Au ${ }^{1}$, \\ Carl G. Meyer ${ }^{1}$, Kevin B. Wong ${ }^{3}$, Russell E. Brainard ${ }^{3}$ \\ ${ }^{1}$ Hawaii Institute of Marine Biology, University of Hawaii, 46-007 Lilipuna Rd., Kaneohe, Hawaii 96744, USA \\ ${ }^{2}$ Joint Institute for Marine and Atmospheric Research, University of Hawaii, 1000 Pope Road, MSB312, Honolulu, \\ Hawaii 96822, USA \\ ${ }^{3}$ NOAA Fisheries, Pacific Islands Fisheries Science Center, Coral Reef Ecosystem Division, 1125 B Ala Moana Blvd., \\ Honolulu, Hawaii 96814, USA
}

\begin{abstract}
The main Hawaiian Islands (MHI) are the principal breeding ground for humpback whales in the North Pacific. Over the past 3 decades, population recovery from whaling-era losses has resulted in a steady increase in the number of whales wintering in Hawaiian waters and a geographic expansion of their distribution in the MHI. Until recently, no existing evidence showed that this expansion included the islands, atolls, and banks of the Northwestern Hawaiian Islands (NWHI). To better understand the occurrence of humpback whales in the NWHI, 9 ecological acoustic recorders (EARs) were deployed at sites throughout the archipelago to record the occurrence of humpback whale song, an indicator of winter breeding activity. Song was found to be prevalent at Maro Reef, Lisianski Island, and French Frigate Shoals but was also recorded at Kure Atoll, Midway Atoll, and Pearl and Hermes Atoll. Both the timing and abundance of song at several locations closely followed trends observed on Oahu, which is one of the MHI, strongly suggesting that humpback whales use the NWHI as a wintering area. This finding is of particular relevance in light of recent suggestions that, based on photo-identification data, a yet undocumented wintering area exists somewhere in the central North Pacific. We propose that the NWHI could be that area.
\end{abstract}

KEY WORDS: Humpback whale Acoustics $\cdot$ Hawaiian Islands $\cdot$ Wintering grounds $\cdot$ Ecological acoustic recorder $\cdot$ EAR

Resale or republication not permitted without written consent of the publisher

\section{INTRODUCTION}

Humpback whales Megaptera novaeangliae in the North Pacific were heavily depleted by whaling during the first half of the 20th century. It is estimated that in 1966, when commercial whaling ceased, the number of animals had been reduced to between 1200 (Johnson \& Wolman 1984) and 1400 (Gambell 1976) animals. Since the 1970s, however, numbers have steadily increased, and now the total abundance in the North Pacific is estimated at $\sim 20000$ whales (Calambokidis et al. 2008). As a result, a review of their status under the
United States Endangered Species Act is currently underway (Federal Register 2009).

Humpback whales are migratory and hold the record for the longest migration distance of any mammal ( 8300 km; Rasmussen et al. 2007). Migrations are made by all age classes and both genders of the species (Dawbin 1966). During the fall months, whales travel from high to low latitudes and spend the winter months engaged in activities related to reproduction, including giving birth, nursing newborn calves, weaning yearlings, and competing for mates (Darling \& Jurasz 1983, Darling \& McSweeney 1985, Baker et al. 
1986). In late winter and spring, the route is reversed and whales return to more biologically productive higher latitudes to spend the summer months feeding (Baker et al. 1986, Calambokidis et al. 2001).

One of the behavioral characteristics of males on the breeding grounds is the production of an elaborate display of song (Payne \& McVay 1971, Winn \& Winn 1978). Humpback whale song is complex, with acoustically distinct units ordered into phrases and themes (Payne \& McVay 1971, Frumhoff 1983, Payne et al. 1983, Au et al. 2006). Males on the same wintering ground and in the same breeding population sing approximately the same song (Winn \& Winn 1978, Helweg et al. 1998, Cerchio et al. 2001), but the song differs in content between breeding populations (Payne \& Guinee 1983). There is presently no consensus about the behavioral function of song, but several explanations have been proposed, including: a display of fitness to females (Winn \& Winn 1978, Tyack 1981, Smith et al. 2008), a display to other males (Darling et al. 2006), an orientation signal used as a migratory beacon by other whales (Clapham \& Mattila 1990), a spacing mechanism between males (Frankel et al. 1995), an acoustic stimulus to induce female estrous (Baker \& Herman 1984), and the production of a sonar signal to help males locate females (Frazer \& Mercado 2000). Irrespective of the function, the occurrence of song in an area is an excellent indicator of humpback whale presence. Au et al. (2000) demonstrated that the sound pressure level of chorusing (song produced by multiple males) changes over the course of the breeding season and is a reliable metric for establishing the timeline of arrival, peak density, and departure of whales on the wintering ground.

The main Hawaiian Islands (MHI) are the principal wintering ground for North Pacific humpback whales. Between 8500 and 10000 whales, or nearly half of the estimated basin-wide population, migrate to Hawaii each winter (Calambokidis et al. 2008). Other known wintering areas in the North Pacific include the Ogasawara Islands, Okinawa, Taiwan, the Philippines, the Mariana Islands, Baja California, the Pacific coast of Mexico, the Revillagigedo Archipelago, and the Pacific coasts of Guatemala, El Salvador, Nicaragua, and Costa Rica (Calambokidis et al. 2008).

In Hawaii, a steady increase in the number of whales overwintering has resulted in an expansion of their distribution across the main archipelago (Mobley et al. 1999). Still unresolved is the extent to which this expansion has included the Northwestern Hawaiian Islands (NWHI), a chain of remote, mostly uninhabited atolls, small islands, and shallow banks stretching $2000 \mathrm{~km}$ to the northwest of the MHI (see Fig. 1). In 2006, these islands and their associated offshore waters were designated the Papahānaumokuākea Marine
National Monument (PMNM), one of the largest marine protected areas in the world. Because they are so remote, most islands and banks in the NWHI are visited infrequently by humans, particularly during winter months when ocean conditions are generally hazardous to mariners. Historically, humpback whales were not thought to occur in the NWHI (Herman \& Antinoja 1977, Herman 1979), but in 2006, a National Oceanic and Atmospheric Administration (NOAA) cetacean survey reported multiple sightings, suggesting a larger presence than previously believed (Johnston et al. 2007).

The present study examined the occurrence of humpback whales in the NWHI using an acoustic monitoring approach similar to the one employed by $\mathrm{Au}$ et al. (2000). Bottom-moored, long-term recorders deployed in both the NWHI and MHI were used to meet 3 specific objectives: (1) to determine whether humpback whales engage in wintering behavior in the NWHI as indicated by the presence of male singing behavior; (2) to establish where in the NWHI archipelago whale occurrence is highest; and (3) to determine whether/how the timing of occurrence in the NWHI is different from known wintering areas in the MHI.

\section{MATERIALS AND METHODS}

The presence of wintering humpback whales was established by monitoring shallow waters in the NWHI for the incidence of song using bottom-moored ecological acoustic recorders (EARs) (Lammers et al. 2008). The EAR is a microprocessor-based autonomous recorder that samples the ambient sound field on a programmable duty cycle. Between 11 June and 4 October 2008, 7 EARs were deployed in the NWHI through a collaborative partnership between the Hawaii Institute of Marine Biology, the PMNM, and the NOAA Pacific Islands Fisheries Science Center. The EARs were programmed to record for $30 \mathrm{~s}$ every $15 \mathrm{~min}$ at a sampling rate of $40 \mathrm{kHz}$. To compare results obtained in the NWHI with the occurrence of humpback whale song in the MHI, 2 EARs were also deployed off the island of Oahu at sites known to have high whale abundance during winter months. The deployment locations, depths, and recording periods of each EAR are shown in Fig. 1 and Table 1.

Data obtained from each EAR were processed using a custom Matlab script. An automated short-time Fourier-transform approach was used to find periods where tonal peaks greater than $3 \mathrm{~dB}$ above the averaged noise floor were present in the frequency spectrum below $2 \mathrm{kHz}$ (Lammers et al. 2008). These periods were summed for each recording and those with 


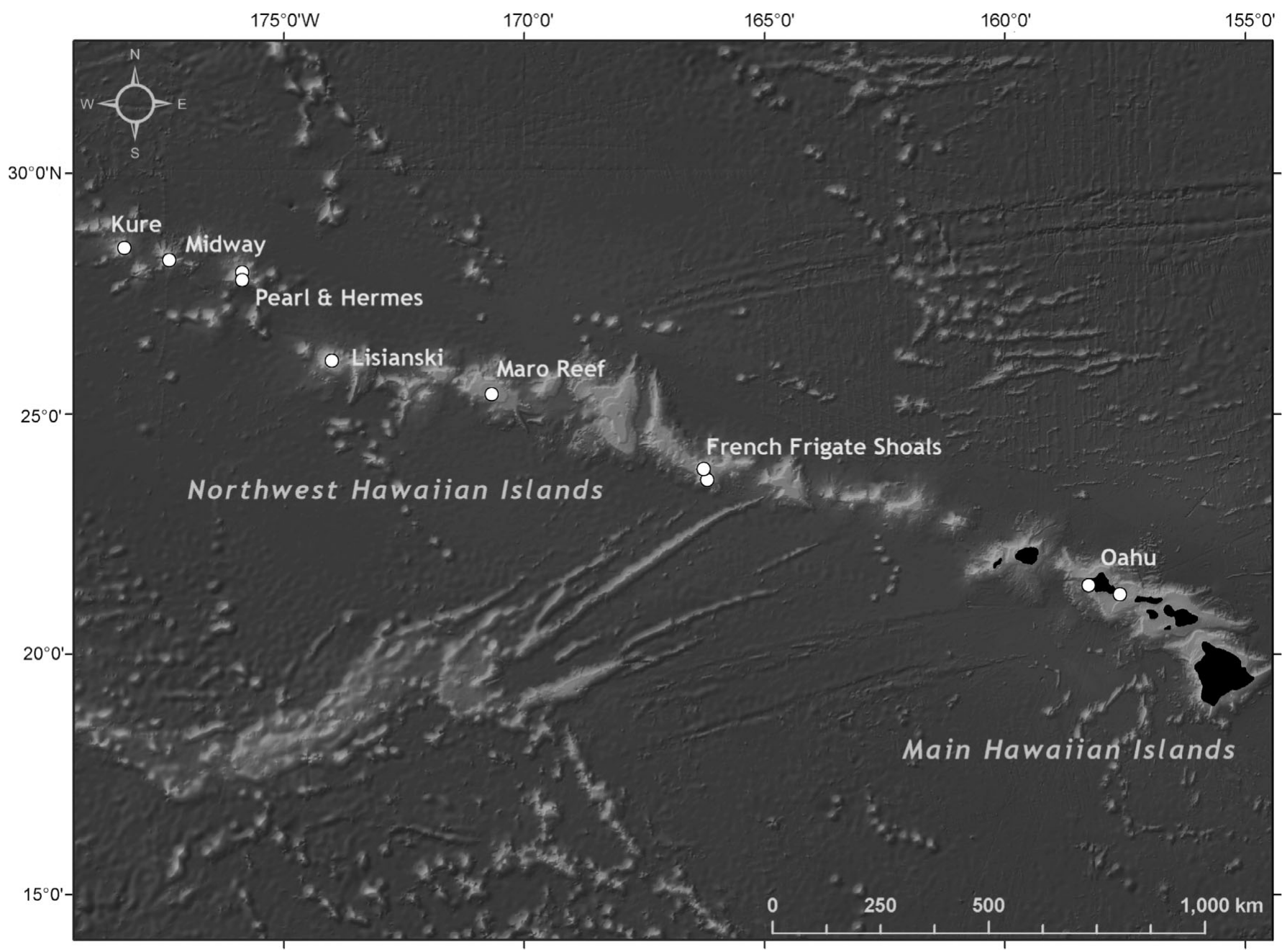

Fig. 1. Locations of the ecological acoustic recorders (EARs; O) in the Hawaiian Archipelago

tonality exceeding $1 \%$ of the total recording time were considered to potentially contain whale song. To establish daily presence or absence of song at each site, recordings for each day were ranked by their

Table 1. Location, deployment depth, and recording period of each ecological acoustic recorder (EAR). Dates in parentheses indicate that the EAR stopped recording prior to the end of the wintering season (Kure Atoll and FFS2) or that the EAR was deployed following the start of the season (Makapu'u). FFS1 and FFS1: French Frigate Shoals sites 1 and 2

\begin{tabular}{|lrrl|}
\hline Location & Coordinates & $\begin{array}{c}\text { Depth } \\
(\mathrm{m})\end{array}$ & $\begin{array}{c}\text { Recording period } \\
\text { (mm/dd/yy) }\end{array}$ \\
\hline Kure Atoll & $28^{\circ} 22.9^{\prime} \mathrm{N}, 178^{\circ} 19.5^{\prime} \mathrm{W}$ & 12.5 & $09 / 29 / 08$ to $(03 / 23 / 09)$ \\
Midway Atoll & $28^{\circ} 11.8^{\prime} \mathrm{N}, 177^{\circ} 22.5^{\prime} \mathrm{W}$ & 14.3 & $09 / 25 / 08$ to $10 / 23 / 09$ \\
Pearl and Hermes Atoll $27^{\circ} 47.5^{\prime} \mathrm{N}, 175^{\circ} 51.8^{\prime} \mathrm{W}$ & 11.5 & $06 / 11 / 08$ to $07 / 07 / 09$ \\
Lisianski Island & $26^{\circ} 6.0^{\prime} \mathrm{N}, 173^{\circ} 59.9^{\prime} \mathrm{W}$ & 22.6 & $10 / 04 / 08$ to $09 / 29 / 09$ \\
Maro Reef & $25^{\circ} 25.2^{\prime} \mathrm{N}, 170^{\circ} 40.1^{\prime} \mathrm{W}$ & 11.6 & $12 / 02 / 08$ to $06 / 10 / 09$ \\
FFS2 & $23^{\circ} 46.1^{\prime} \mathrm{N}, 166^{\circ} 15.7^{\prime} \mathrm{W}$ & 10.1 & $09 / 15 / 08$ to $(03 / 23 / 09)$ \\
FFS1 & $23^{\circ} 38.1^{\prime} \mathrm{N}, 166^{\circ} 11.1^{\prime} \mathrm{W}$ & 23.8 & $09 / 14 / 08$ to $07 / 07 / 09$ \\
Makua, Oahu & $21^{\circ} 31.9^{\prime} \mathrm{N}, 158^{\circ} 14.1^{\prime} \mathrm{W}$ & 19.8 & $10 / 03 / 08$ to $07 / 05 / 09$ \\
Makapu'u, Oahu & $21^{\circ} 17.7^{\prime} \mathrm{N}, 157^{\circ} 33.4^{\prime} \mathrm{W}$ & 161 & $(02 / 07 / 09)$ to $06 / 09 / 09$ \\
\hline
\end{tabular}

percent tonality and then visually examined using the program CoolEdit ${ }^{\mathrm{TM}}$ (Adobe). For each day, recordings were examined serially until either whale song was confirmed or all files with tonality exceeding $1 \%$ were exhausted. In addition, to investigate the relative abundance of song by location and across time, $10 \%$ of recordings from each site were randomly selected for each month and visually and aurally examined for the presence of song. This provided a proportional measure of the number of recordings per month in each data set that contained song.

To evaluate whether song detectability due to ambient noise was equivalent at each site, baseline levels were compared by calculating the average root-mean-square (RMS) sound pressure level (SPL) in the 0 to $2 \mathrm{kHz}$ frequency band for recordings obtained 
during a period of $2 \mathrm{wk}$ prior to the first incidence of song. For all sites except Maro Reef and Makapu'u, Oahu, the period used was from 24 November to 7 December 2008. For Maro Reef, data were not available for November 2008, so the period from 2 December to 15 December 2008 was used instead. For Makapu'u, data collection did not begin until February 2009, so RMS SPLs were calculated from 24 November to 7 December 2009, obtained during a subsequent re-deployment of the EAR at the site.

\section{RESULTS}

Humpback whale song was recorded at all 7 sites in the NWHI and at both locations off Oahu (Fig. 2). Table 2 provides a summary of the occurrence of song at each location measured by its daily incidence, as well as the averaged ambient noise level for that location. The earliest occurrence in the NWHI was at French Frigate Shoals on 8 December 2008, and the latest was at Maro Reef on 28 May 2009. In the MHI,
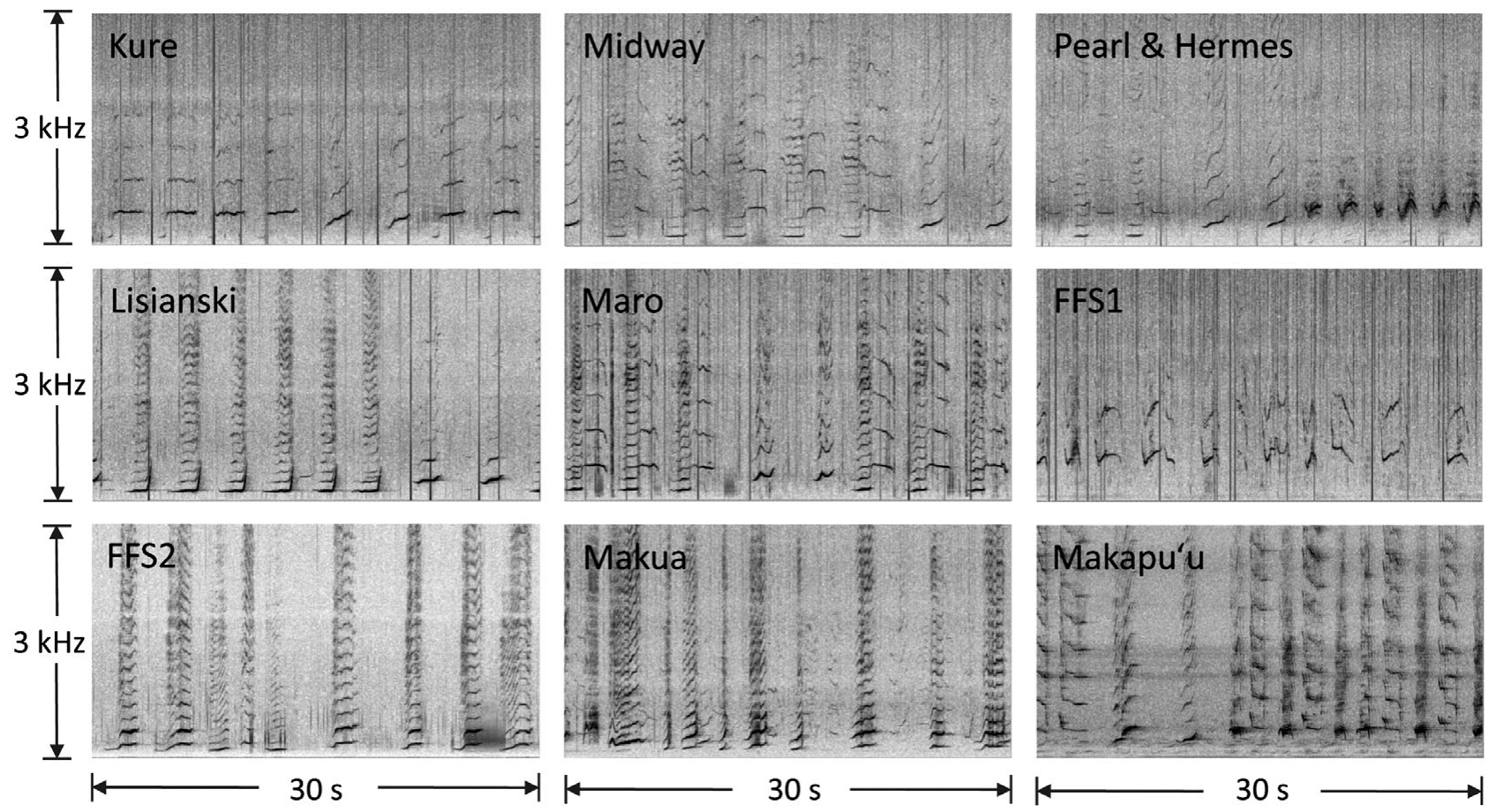

Fig. 2. Megaptera novaeangliae. Spectrograms of humpback whale song recorded at each deployment location. FFS1 and FFS1: French Frigate Shoals sites 1 and 2

Table 2. Megaptera novaeangliae. Timing of the first and last occurrence of song at each ecological acoustic recorder (EAR) deployment location, number of days with song present relative to the singing season (first occurrence to last occurrence), and average ambient noise level calculated for each location. Dates in parentheses indicate that the EAR stopped recording before song occurrence ceased (Kure Atoll and FFS2) or that the EAR was deployed following the start of the wintering season (Makapu'u).

FFS1 and FFS1: French Frigate Shoals sites 1 and 2; RMS: root mean square; re $1 \mu \mathrm{Pa}$ : reference level of $1 \mu \mathrm{Pa}$

\begin{tabular}{|lcccc|}
\hline Location & $\begin{array}{c}\text { First occurrence of } \\
\text { whale song (mm/dd/yy) }\end{array}$ & $\begin{array}{c}\text { Last occurrence of } \\
\text { whale song (mm/dd/yy) }\end{array}$ & $\begin{array}{c}\text { Days with song/days } \\
\text { of singing season }(\%)\end{array}$ & $\begin{array}{c}\text { Averaged }( \pm \text { SD) ambient } \\
\text { noise in dB RMS re } 1 \mu \text { Pa }\end{array}$ \\
\hline Kure Atoll & $01 / 16 / 09$ & $(3 / 23 / 09)$ & $39 / 61(63.9)$ & $103.9 \pm 2.4$ \\
Midway Atoll & $02 / 04 / 09$ & $04 / 07 / 09$ & $6 / 62(9.7)$ & $100.3 \pm 2.3$ \\
Pear and Hermes Atoll & $01 / 08 / 09$ & $04 / 30 / 09$ & $41 / 112(36.6)$ & $102.3 \pm 2.4$ \\
Lisianski Island & $12 / 21 / 08$ & $05 / 19 / 09$ & $111 / 148(75)$ & $101.7 \pm 5.2$ \\
Maro Reef & $12 / 19 / 08$ & $05 / 28 / 09$ & $153 / 161(95)$ & $106.1 \pm 3.9$ \\
FFS2 & $12 / 08 / 08$ & $(03 / 23 / 09)$ & $82 / 103(79.6)$ & $91.1 \pm 2.4$ \\
FFS1 & $12 / 11 / 08$ & $04 / 29 / 09$ & $116 / 140(82.9)$ & $105.8 \pm 3.4$ \\
Makua, Oahu & $12 / 20 / 08$ & $05 / 26 / 09$ & $133 / 157(84.7)$ & $100.4 \pm 2.5$ \\
Makapu'u, Oahu & $(02 / 07 / 09)$ & $06 / 02 / 09$ & $107 / 122(87.7)$ & $97.3 \pm 4.2$ \\
\hline
\end{tabular}


off Oahu, song was first recorded at Makua on 20 December 2008 and was last recorded at Makapu'u on 2 June 2009. Of the 9 sites monitored, Maro Reef had the highest incidence of song between the first and last detections, with $95 \%$ of the intervening days marked by the presence of song. The next highest incidence of song occurred at the 2 Oahu locations with $87.7 \%$ (Makapu'u) and $84.7 \%$ (Makua), followed by the 2 French Frigate Shoals sites at $82.9 \%$ (FFS1) and 79.6\% (FFS2) and Lisianski at $75 \%$. The lowest incidence of song occurred at the 3 northwesternmost sites of the archipelago. At Pearl and Hermes Atoll, song was first recorded on 8 January 2009 and last on 30 April 2009. During this period, song occurred on $41 \mathrm{~d}$ (36.6\%). At Kure Atoll, song first occurred on 16 January 2009, but the EAR stopped recording on 23 March 2009, so it cannot be determined when singing ceased. During that period, song was recorded on $39 \mathrm{~d}(63.9 \%)$. The lowest incidence was at Midway Atoll where song was only recorded on $6 \mathrm{~d}$ between 4 February and 7 April $2009(9.7 \%)$.

Averaged ambient noise levels in the 0 to $2 \mathrm{kHz}$ band ranged from $91.1 \mathrm{~dB}$ RMS with reference level of $1 \mu \mathrm{Pa}$ (re $1 \mu \mathrm{Pa}$ ) at FFS1 to $106.1 \mathrm{~dB}$ RMS at Maro Reef, a $15 \mathrm{~dB}$ variation. However, 7 of the 9 sites varied by less than $5.8 \mathrm{~dB}$. A linear regression analysis revealed no correlation between ambient noise levels and the number of days that song was detected at a location $\left(\mathrm{R}^{2}=\right.$ $2.7 \%, \mathrm{p}=0.674)$.

Fig. 3 shows the percentage of recordings containing song (RCS) for each month by deployment location. The 3 northwesternmost atolls (Kure, Midway, and Pearl and Hermes) showed the lowest abundance of song. Of these, Kure Atoll had the highest, with 13.9\% RCS in February, Pearl and Hermes Atoll was second with 9.1\% RCS in March, and Midway Atoll had the least song with only $3.0 \%$ RCS in February.

These results contrast with those obtained at the 3 other locations farther south along the archipelago. At Lisianski Island, song steadily increased from January to February and peaked in March with $82.6 \%$ RCS. At Maro Reef, more than $85 \%$ of recordings had whale song present in both February and April, and peaked in March at $98.1 \%$ RCS. Finally, both EAR sites at French Frigate Shoals showed moderate song abundance, with peaks of $37.6 \%$ RCS in January at FFS1 and $57.6 \%$ RCS in February at FFS2.

At the 2 locations off the island of Oahu, whale song abundance was similar to French Frigate Shoals and Maro Reef. At the Makua site, there was a steady increase in RCS from December to April, with a peak at $52.6 \%$ RCS, followed by a rapid decline in May. The EAR at Makapu'u was not deployed until 7 February, so no data are available to assess the abundance of song in December and January, but song was nearly ubiquitous in February and March, with more than 97.0\% RCS during both months.

Table 3 presents a statistical comparison of song abundance by month among the 4 locations in the NWHI with the highest incidence (Maro Reef, Lisianski Island, FFS1, and FFS2) and the 2 Oahu locations. Makapu'u exhibited a greater abundance of whale song than all NWHI locations during all months except in February when whale song density was equivalent to that in Maro Reef. Alternatively, Makua tended to have less song in January than most sites in the NWHI, but equivalent or greater levels later in the season.

\section{DISCUSSION}

The temporal occurrence and abundance of song recorded at each site provides strong evidence that humpback whales are common in the NWHI from late December to mid-May. Moreover, a comparison of the incidence of song on Oahu with the NWHI reveals that many locations show equivalence in song prevalence, suggesting whales use at least parts of the NWHI as a wintering ground much like the MHI. Although absolute numbers of whales occurring at each location cannot be inferred from the data, a relative comparison of song persistence (\% days with song) and abundance (\% RCS) indicates that Maro Reef, Lisianski Island, French Frigate Shoals, and the 2 Oahu locations are comparable. Maro Reef, in particular, stands out as a hub of whale activity in the NWHI by matching or exceeding song abundance and persistence at Makapu'u. The shallow (<200 m) waters extending from Makapu'u Point on Oahu are well known locally as a habitat used by wintering whales and are part of NOAA's Hawaiian Islands Humpback Whale National Marine Sanctuary.

The northernmost atolls of Kure, Midway, and Pearl and Hermes exhibited notably less humpback whale song presence. Although small peaks in activity occurred in February and March, both song persistence and abundance were comparatively much lower than at other locations. The data do not provide a way to evaluate whether this difference reflects fewer whales wintering at the northern atolls or a fundamentally different pattern of occurrence or behavioral use of this habitat. Rasmussen et al. (2007) demonstrated that, globally, humpback whales winter in waters with average sea surface temperatures $>21.1^{\circ} \mathrm{C}$, which Johnston et al. (2007) report is greater than the average temperature at Kure, Midway, and Pearl and Hermes Atolls between January and March. Therefore, it is possible that songs recorded at the northern atolls come from whales that only pass through the area rather than ones wintering there. 

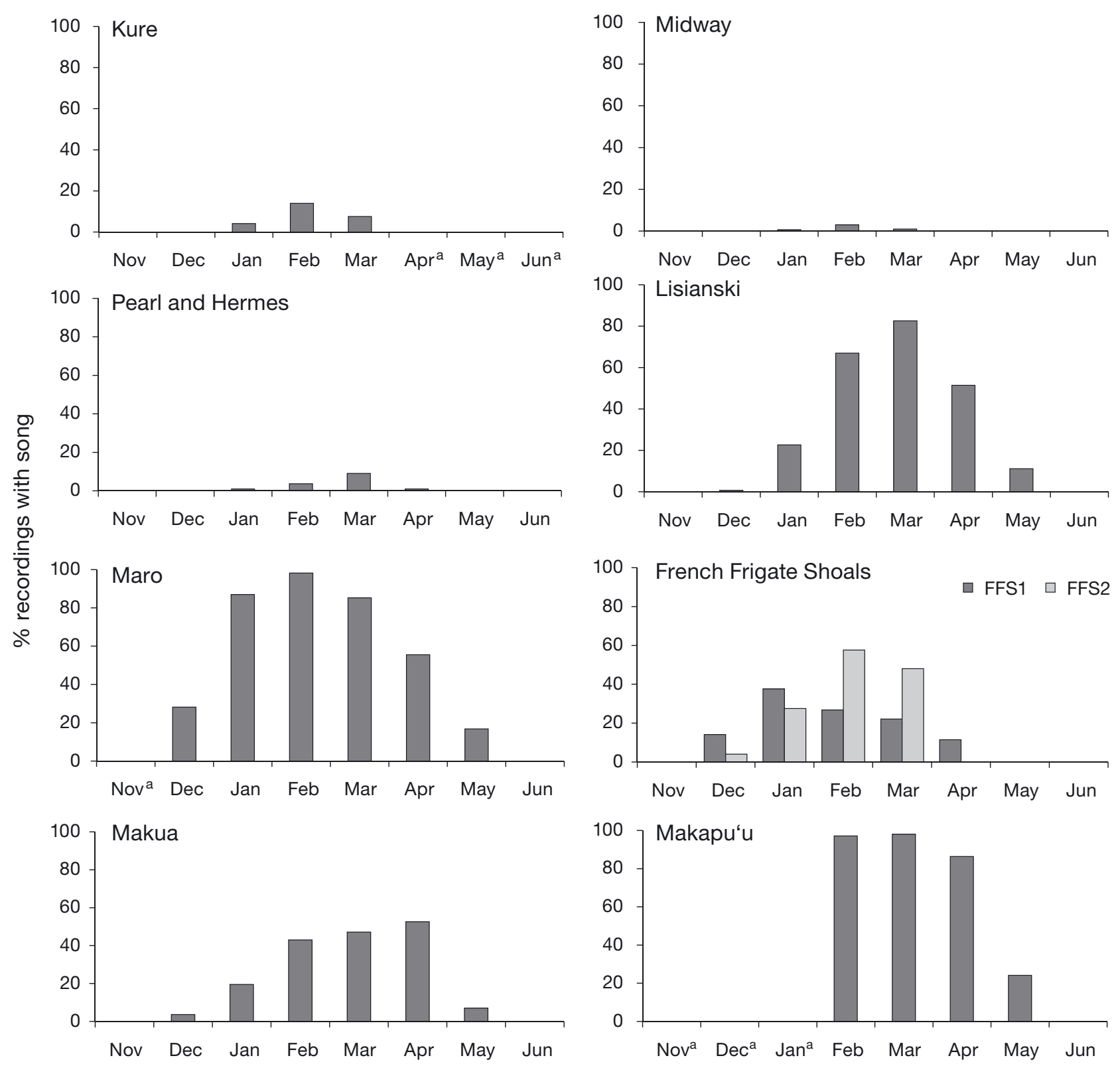

Fig. 3. Megaptera novaeangliae. Abundance of humpback whale song across the archipelago measured by the percentage of ecological acoustic recorder (EAR) recordings containing song for each month by deployment location (see Table 1). ${ }^{\text {DData }}$ were not available because the EAR was not deployed or did not record. FFS1 and FFS1: French Frigate Shoals sites 1 and 2

The detectability of song between recording locations was likely influenced by a variety of factors, including the EAR's proximity to singing whales, ambient noise, bathymetry, and the local sound-transmission environment (which will change with water depth). Of these factors, only ambient noise could be readily quantified. Although there was variability in noise between sites, it did not correlate with the amount of song detected. Therefore, it is reasonable to conclude that noise was at least not a major confounding variable in the results. The depth of 8 of the 9 EARs sites varied only between 10.1 and $23.8 \mathrm{~m}$, so the sound-transmission environments of these units can be assumed to be approximately comparable. However, the EAR located off Makapu'u was considerably deeper (161 m), making it likely that this site's transmission environment differed from the rest, possibly increasing the listening range of the EAR. This may have increased the detectability of song at this site and might help explain the higher abundance and persistence of song observed at 
Table 3. Megaptera novaeangliae. Chi-squared statistical comparison of song abundance (no. of recordings with song present vs. absent) by month among 4 Northwestern Hawaiian Islands (NWHI) ecological acoustic recorder (EAR) sites and the 2 Oahu sites (Makua and Makapu'u). The '=' symbol indicates that the comparison was not significantly different, ' $>$ ' indicates that song abundance was significantly greater at the NWHI site, ' $<$ ' indicates that abundance was greater at the Oahu site. FFS1 and FFS1: French Frigate Shoals sites 1 and 2; nd: no data available

\begin{tabular}{|c|c|c|c|c|c|c|c|}
\hline \multirow{2}{*}{ NWHI } & \multirow{2}{*}{ Month } & \multicolumn{3}{|c|}{ Makua } & \multicolumn{3}{|c|}{ Makapu'u } \\
\hline & & Comparison & $\chi^{2}$ & $\mathrm{p}$ & Comparison & $\chi^{2}$ & $\mathrm{p}$ \\
\hline \multirow[t]{5}{*}{ Lisianski } & Jan & $=$ & 0.860 & 0.354 & nd & nd & nd \\
\hline & Feb & $>$ & 30.231 & $<0.001$ & $<$ & 65.558 & $<0.001$ \\
\hline & Mar & $>$ & 81.859 & $<0.001$ & $<$ & 39.761 & $<0.001$ \\
\hline & Apr & $=$ & 0.086 & 0.769 & $<$ & 81.351 & $<0.001$ \\
\hline & May & $=$ & 2.889 & 0.089 & $<$ & 17.473 & $<0.001$ \\
\hline \multirow[t]{5}{*}{ Maro } & Jan & $>$ & 271.332 & $<0.001$ & nd & nd & nd \\
\hline & Feb & $>$ & 194.937 & $<0.001$ & $=$ & 0.598 & 0.439 \\
\hline & Mar & $>$ & 96.511 & $<0.001$ & $<$ & 30.987 & $<0.001$ \\
\hline & Apr & $=$ & 0.501 & 0.479 & $<$ & 65.634 & $<0.001$ \\
\hline & May & $>$ & 13.340 & $<0.001$ & $<$ & 4.945 & 0.026 \\
\hline \multirow[t]{5}{*}{ FFS1 } & Jan & $>$ & 23.761 & $<0.001$ & nd & nd & nd \\
\hline & Feb & $<$ & 15.356 & $<0.001$ & $<$ & 233.996 & $<0.001$ \\
\hline & Mar & $<$ & 41.041 & $<0.001$ & $<$ & 353.815 & $<0.001$ \\
\hline & Apr & $<$ & 111.890 & $<0.001$ & $<$ & 321.300 & $<0.001$ \\
\hline & May & $<$ & 21.842 & $<0.001$ & $<$ & 81.773 & $<0.001$ \\
\hline \multirow[t]{3}{*}{ FFS2 } & Jan & $>$ & 5.275 & 0.022 & nd & nd & nd \\
\hline & Feb & $>$ & 11.226 & 0.001 & $<$ & 95.305 & $<0.001$ \\
\hline & Mar & $=$ & 0.043 & 0.836 & $<$ & 186.658 & $<0.001$ \\
\hline
\end{tabular}

very similar to that observed on Oahu, which argues against the steppingstone hypothesis. Such a pattern would presumably be characterized by song beginning earlier and persisting later in the NWHI than the MHI. In addition, previous work using satellite telemetry has shown that, out of 6 whales tagged in the MHI, none traveled to the NWHI and 3 whales left the MHI on independent, parallel courses toward the upper Gulf of Alaska traveling with a heading within $1^{\circ}$ of magnetic north (Mate et al. 1998). In other words, their northbound migration path took them several hundred $\mathrm{km}$ east of the NWHI.

An intriguing possibility is that the humpback whales wintering in the NWHI represent a previously undocumented breeding stock. Calambokidis et al. (2008) recently revealed that, based on photo-identification and genetic sampling of the North Pacific humpback whale population, a previously unknown wintering ground exists somewhere in the central North Pacific. This conclusion was reached because whales feeding in the Aleu-

Makapu'u. A quantitative evaluation of the different transmission environments is beyond the scope of the present study, but would need to be considered in any future effort to use song presence to estimate absolute whale abundance.

The presence of a considerable population of wintering humpback whales in the NWHI, while historically not documented, is not entirely unexpected. In addition to reporting several sightings, Johnston et al. (2007) used spatial modeling to calculate the amount of shallow $(<200 \mathrm{~m})$, warm-water habitat preferred by wintering whales available throughout the Hawaiian Archipelago. Their calculations revealed that the NWHI have nearly twice the available habitat as the MHI. Therefore, although the actual number of whales that use the NWHI is still unknown, it is clear that many locations are well suited to host wintering humpback whales.

An unresolved question is whether the whales occurring in the NWHI and the MHI are part of the same wintering population. The movement of whales between islands in the MHI is well documented (Mate et al. 1998), but it is presently unclear whether whales in the NWHI represent an extension of these movements and whether whales might follow the NWHI as migratory stepping stones to and from the MHI. The timing of occurrence of whales in the NWHI is, for the most part, tians and the Bering Sea during summer are not well represented in the catalogs of known North Pacific wintering areas and, therefore, must be wintering elsewhere. Whether the NWHI are in fact this 'missing breeding ground' cannot be answered here and, of course, other candidate locations must be considered as well (e.g. the Northern Mariana Islands, Guam, Wake Island, etc.). However, geographically, the NWHI are the nearest wintering habitat available to whales traveling from the Aleutians, making them perhaps the most logical destination. Presently, an effort is underway (authors unpubl.) to quantitatively compare the song structure from the NWHI to that of the 2 Oahu sites. Differences in the song, if present, may shed light on whether the NWHI are an extension of the MHI wintering area or a distinct wintering ground.

Finally, it should be noted that the information presented here underscores the value of passive acoustic technologies for monitoring biological activities in marine ecosystems, particularly secluded marine protected areas. The remoteness of the NWHI would have made obtaining these or similar data using traditional surveys logistically very difficult and prohibitively expensive. In addition, the synoptic view presented here, with multiple, simultaneous, long-term observations made over a vast area, would be nearly impossible to achieve by almost any other methods. Continuing 
advancements in acoustic monitoring technologies are sure to become increasingly important in future investigations of many biological phenomena and ecological trends occurring in remote marine habitats.

Acknowledgments. We thank K. McCoy, N. Pomeroy, and A. Rosinski for their assistance with data processing and the NOAA Pacific Islands Fisheries Science Center's Coral Reef Ecosystem Division (CRED) Oceanography team for their help deploying and recovering EARs. We also thank K. Sexton and M. Richlen for their roles in manufacturing EARs and L. Munger for reviewing an earlier draft of this manuscript. This work was supported by the NOAA/HIMB Northwestern Hawaiian Islands Partnership Program and the NOAA Coral Reef Conservation Program. This is Hawaii Institute of Marine Biology publication number 1390.

\section{LITERATURE CITED}

Au WWL, Mobley J, Burgess WC, Lammers MO, Nachtigall PE (2000) Seasonal and diurnal trends of chorusing humpback whales wintering in waters off western Maui. Mar Mamm Sci 16:530-544

Au WWL, Pack AA, Lammers MO, Herman LM, Deakos M, Andrews K (2006) Acoustic properties of humpback whale song. J Acoust Soc Am 120:1103-1110

Baker CS, Herman LM (1984) Aggressive behaviour between humpback whales (Megaptera novaeangliae) wintering in Hawaiian waters. Can J Zool 62:1922-1937

Baker CS, Herman LM, Perry A, Lawton WS and others (1986) Migratory movement and population structure of humpback whales (Megaptera novaeangliae) in the central and eastern North Pacific. Mar Ecol Prog Ser 31:105-119

Calambokidis J, Steiger GH, Straley JM, Herman LM and others (2001) Movements and population structure of humpback whales in the North Pacific. Mar Mamm Sci 17: 769-794

Calambokidis J, Falcone EA, Quinn TJ, Burdin AM and others (2008) SPLASH: structure of populations, levels of abundance and status of humpback whales in the North Pacific. Final report for contract AB133F-03-RP-00078. Cascadia Research, Olympia, WA

Cerchio S, Jacobsen JK, Norris TF (2001) Temporal and geographical variation in songs of humpback whales, Megaptera novaeangliae: synchronous change in Hawaiian and Mexican breeding assemblages. Anim Behav 62: 313-329

Clapham PJ, Mattila DK (1990) Humpback whale songs as indications of migration routes. Mar Mamm Sci 6:155-160

Darling JD, Jurasz CM (1983) Migratory destinations of North Pacific humpback whales (Megaptera novaeangliae). In: Payne R (ed) Communication and behavior of whales. Westview Press, Boulder, CO, p 359-368

$>$ Darling JD, McSweeney DJ (1985) Observations of the migrations of North Pacific humpback whales (Megaptera novaeangliae). Can J Zool 63:308-314

Darling JD, Jones ME, Nicklin CP (2006) Humpback whale songs: do they organize males during the breeding season? Behaviour 143:1051-1101

Dawbin WH (1966) The seasonal migratory cycle of humpback whales. In: Norris KS (ed) Whales, dolphins and porpoises. University of California Press, Berkeley, CA, p 145-170

Federal Register (2009) Endangered and Threatened species; initiation of a status review for the humpback whale and request for information. Federal Register 74 (154):40568

Frankel AS, Clark CW, Herman LM, Gabriele CM (1995) Spatial distribution, habitat utilization, and social interactions of humpback whales, Megaptera novaeangliae, off Hawai'i, determined using acoustic and visual techniques. Can J Zool 73:1134-1146

Frazer LN, Mercado E (2000) A sonar model for humpback whale song. IEEE J Ocean Eng 25:160-181

Frumhoff P (1983) Aberrant songs of humpback whales (Megaptera novaeangliae): clues to the structure of humpback songs. In: Payne R (ed) Communication and behavior of whales. Westview Press, Boulder, CO, p 81-127

- Gambell R (1976) World whale stocks. Mammal Rev 6:41-53

Helweg DA, Cato DH, Jenkins PF, Garrigue C, McCauley RD (1998) Geographic variation in South Pacific humpback whale songs. Behaviour 135:1-27

Herman LM (1979) Humpback whales in Hawaiian waters: a study in historical ecology. Pac Sci 33:1-15

Herman LM, Antinoja RC (1977) Humpback whales in the Hawaiian breeding water: population and pod characteristics. Sci Rep Whales Res Inst Tokyo 29:59-85

Johnson JH, Wolman AA (1984) The humpback whale, Megaptera novaeangliae. Mar Fish Rev 46:30-37

Johnston DW, Chapla ME, Williams LE, Mattila DK (2007) Identification of humpback whale Megaptera novaeangliae wintering habitat in the Northwestern Hawaiian Islands using spatial habitat modeling. Endang Species Res 3:249-257

Lammers MO, Brainard RE, Au WWL, Mooney TA, Wong K (2008) An ecological acoustic recorder (EAR) for long-term monitoring of biological and anthropogenic sounds on coral reefs and other marine habitats. J Acoust Soc Am 123:1720-1728

Mate BR, Gisiner R, Mobley J (1998) Local and migratory movements of Hawaiian humpback whales tracked by satellite telemetry. Can J Zool 76:863-868

Mobley JR, Bauer GB, Herman LM (1999) Changes over a ten-year interval in the distribution and relative abundance of humpback whales (Megaptera novaeangliae) wintering in Hawaiian waters. Aquat Mamm 25:63-72

Payne RS, Guinee LN (1983) Humpback whale songs as an indicator of 'stocks'. In: Payne R (ed) Communication and behavior of whales. Westview Press, Boulder, CO, p 333-358

Payne RS, McVay S (1971) Songs of humpback whales. Science 173:585-597

Payne K, Tyack P, Payne R (1983) Progressive changes in the songs of humpback whales (Megaptera novaeangliae): a detailed analysis of two seasons in Hawaii. In: Payne $\mathrm{R}$ (ed) Communication and behavior of whales. Westview Press, Boulder, CO, p 9-57

- Rasmussen K, Palacios DM, Calambokidis J, Saborío MT and others (2007) Southern Hemisphere humpback whales wintering off Central America: insights from water temperature into the longest mammalian migration. Biol Lett 3:302-305

Smith JN, Goldizen AW, Dunlop RA, Noad MJ (2008) Songs of male humpback whales, Megaptera novaeangliae, are involved in intersexual interactions. Anim Behav 76: 467-477

- Tyack P (1981) Interactions between singing Hawaiian humpback whales and conspecifics nearby. Behav Ecol Sociobiol 8:105-116

Winn HE, Winn LK (1978) The song of the humpback whale (Megaptera novaeangliae) in the West Indies. Mar Biol 47: 97-114 